\title{
ARAŞTIRMA / RESEARCH \\ C-reactive protein to albumin ratio is associated with increased risk of mortality in COVID-19 pneumonia patients
}

C-reaktif protein/albümin oranı COVID-19 pnömonisi olan hastalarda artan mortalite riski ile ilişkilidir

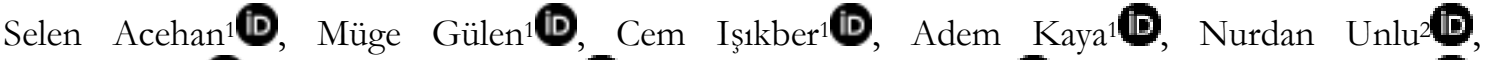

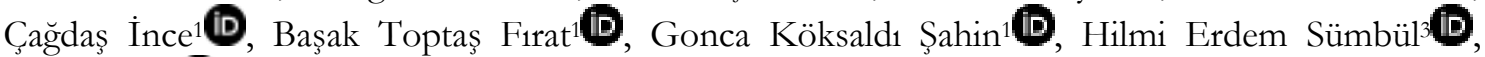 \\ Salim Satar (D)
}

${ }^{1}$ Adana City Training and Research Hospital, Department of Emergency Medicine, ${ }^{2}$ Department of Anesthesiology and Intensive Care, ${ }^{3}$ Department of İnternal Medicine, Adana, Turkey

\section{Abstract}

Purpose: The aim of this retrospective observationa study is to compare $\mathrm{C}$-reactive protein to albumin ratio and CURB-65 score in the emergency department in terms of predicting mortality in patients over the age of 18 who were hospitalized for COVID-19 pneumonia.

Materials and Methods: The study includes 613 patients hospitalized between March 15 and April 30, 2020 due to COVID-19 pneumonia detected on thorax computed tomography at the emergency department pandemic area Hospitalized patients were divided into groups according to positive and negative real-time polymerase chain reaction results.

Results: While $73.1 \%$ (n: 448) of 613 patients included in the study were hospitalized in the ward, $26.9 \%$ (n: 165) were hospitalized in intensive care. $8.6 \%$ (n: 53 ) of the total patients died. In non-survivors patients the mean CURB 65 score was $4 \pm 1$ (and C-Reactive Protein to Albumin Ratio was 5.6 \pm 4.2 Multivariate logistic regression analysis showed that CURB 65 and high C-Reactive Protein to Albumin Ratio are independent risk factors for COVID19 pneumonia.

Conclusion: The $\mathrm{C}$-reactive protein to albumin ratio is as sensitive as CURB 65 and can guide the clinician in the early detection of patients with poor prognosis COVID19 pneumonia.

Keywords:. Reactive protein to albumin ratio, COVID-19 pneumonia, CURB 65, emergency department
Öz

Amaç: $\mathrm{Bu}$ retrospektif gözlemsel çalışmanın amac1, COVID-19 pnömonisi nedeniyle hastaneye yatırlan 18 yaş üstü hastalarda mortaliteyi öngörme açısından acil serviste bakılan C-reaktif protein/albumin oranı ile CURB-65 skorunun karşılaştırılmasıdır.

Gereç ve Yöntem: Çalışma 15 Mart-30 Nisan 2020 tarihleri arasında acil servis pandemi alanında toraks bilgisayarlı tomografisinde COVID-19 pnömonisi tespit edilerek hastaneye yatırılan 613 hastayı kapsamaktadır. Hastanede yatan hastalar pozitif ve negatif gerçek zamanlı polimeraz zincir reaksiyonu sonuçlarına göre gruplara ayrild.

Bulgular: Çalışmaya dahil edilen 613 hastanın \%73,1'i (n:448) serviste yatarken, \%26,9'u (n:165) yoğun bakımda yatmaktaydı. Toplam hastaların \%8,6's1 (n:53) öldü. Ölen hastalarda CURB 65 skoru ortalama $4 \pm 1$ ve C-reaktif

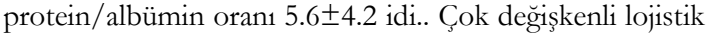
regresyon analizi, CURB 65 skorunu) ve yüksek C-reaktif protein/albümin oranı olduğunu gösterdi.) COVID-19 pnömonisi için bağımsız risk faktörleri olarak göstermiştir. Sonuç: C-reaktif protein/albumin oranı, kötü prognozlu COVID-19 pnömonisi olan hastaların erken tespitinde CURB 65 kadar duyarlı olup klinisyene yol gösterebilir.

Anahtar kelimeler: Acil servis, C-reaktif protein/albümin oranı, COVID-19 pnömonisi, CURB 65, 


\section{INTRODUCTION}

Despite the fact that significant advances in global health have taken place, pneumonia is one of the most common infectious diseases requiring hospitalization and is associated with high morbidity and mortality ${ }^{1,2}$. SARS-CoV-2 (COVID-19), the $7^{\text {th }}$ CoV known after SARS-, CoV and MERS-CoV, is the pathogen of the ongoing new pneumonia epidemic that infects humans ${ }^{3}$.

The most common symptoms of SARS-CoV-2 during admission are respiratory system complaints such as fever, cough and shortness of breath. As of September 10, 2021, the number of cases of this contagious infection worldwide exceeded 219 million laboratory-confirmed cases, and deaths exceeded 4.5 million. Therefore, early isolation and effective treatment of patients infected with COVID-19 are of great importance in terms of reducing mortality and morbidity.

The CURB-65 (Confusion, Urea, Respiratory Rate) score is a pneumonia severity score developed to decide whether to care patients as outpatients or inpatients ${ }^{4}$ and studies have shown that it can also be used to predict mortality ${ }^{5-8}$. In recent studies, the CURB-65 score was found to be significantly higher in deceased COVID-19 patients9, ${ }^{10}$. Studies have shown that CURB 65 can also help clinicians during the COVID 19 pandemic period, as it has simple evaluation criteria and is easy to use in emergency situations. C-reactive protein (CRP) and albumin are used to predict mortality in critically ill patients because of their ability to demonstrate acute inflammatory conditions ${ }^{11,12}$. CRP to albumin ratio, which is the ratio of these two laboratory parameters to each other, is a new and useful indicator that has been used in critical patients with sepsis, septic shock and malignancy ${ }^{13-15}$.

In this study, it is aimed to compare C-reactive protein to albumin ratio (CAR) with CURB-65 score in predicting mortality in patients hospitalized with COVID-19 pneumonia from the emergency department pandemic area.

\section{MATERIALS AND METHOD}

This study was initiated after obtaining the approval of the Republic of Turkey Ministry of Health (202004-30T11_00_36.xml) and the local ethics committee (Approval Date: 06/05/2020, Decision Number: $841 / 56)$. Designed as a retrospective observational case series, the study included 613 patients transferred from the Tertiary hospital emergency department pandemic area to the ward as pneumonia was detected in Thorax computed tomography (CT), between 15/03/2020 and 30/04/2020. Patients under the age of 18 , pregnant women, patients whose files and laboratory data could not be fully accessed, patients whose thorax CT could not be taken and/or whose thorax CT did not have typical pneumonia features were excluded from the study.

\section{Data collection}

Demographic characteristics, vital signs, additional diseases, laboratory parameters, Thorax CT reports, CURB 65 score, COVID-19 Real-time polymerase chain reaction (RT-PCR) test results, duration of hospitalization, mechanical ventilator, vasopressor and renal replacement therapy needs and outcome data of the patients included in the study were obtained from patient files and hospital electronic records and data processing system logs. Patients hospitalized in the emergency department with a diagnosis of pneumonia were divided into groups according to positive and negative RT-PCR results. Demographic characteristics, symptoms, vital signs, comorbidities, clinical and laboratory findings were recorded in the data collection form.

The patients included in the study were screened with a 64-channel multi-detector CT scanner Philips Ingenuity Core 128 (Philips Healthcare Eindhoven, The Netherlands, and June 2017). Radiologists (with at least 5 years of experience) interpreted all thorax CT images according to the COVID-19 Reporting and Data System (CO-RADS) classification, without knowing the clinical features and laboratory findings of the patients. The CO-RADS classification created by The Dutch Radiological Society, from 1 (very low) to 5 (very high), is a radiological diagnostic indicator to evaluate the suspicion of COVID-19 pulmonary involvement ${ }^{16}$.

CO-RADS 1; implies a very low level of suspicion for pulmonary involvement by COVID-19 based on either normal CT results or CT findings of unequivocal noninfectious origin, CO-RADS 2; implies a low level of suspicion for pulmonary involvement by COVID-19 based on CT findings in the lungs typical of infectious origin that are considered not compatible with COVID-19, CORADS 3; implies equivocal findings for pulmonary involvement of COVID-19 based on CT features that can also be found in other viral pneumonias or 
noninfectious causes, CO-RADS 4; implies a high level of suspicion for pulmonary involvement by COVID-19 based on CT findings that are typical for COVID-19 but also show some overlap with other (viral) pneumonias, CO-RADS 5; implies a very high level of suspicion for pulmonary involvement by COVID-19 based on typical CT findings ${ }^{17}$. Patients whose thorax CT findings were classified as CORADS 4 and 5 were included in the study.

Nasopharyngeal and oropharyngeal swab samples were taken from all patients for the diagnosis of COVID-19 in the emergency department. Nucleic acid isolation from nasopharyngeal and oropharyngeal swab samples was conducted using Bio-Speedy ${ }^{\circledR}$ Purification Kit (Bioeksen, Istanbul, Turkey).

Hemogram and biochemical parameters (Lactate dehydrogenase $(\mathrm{LDH}), \quad$ Creatinine, Ferritin, Fibrinogen, D-dimer, Hs-Tn I, CRP, Albumin, and Procalcitonin (PCT)) were taken from all patients in the emergency department. In addition, CRP to albumin ratio (CAR), Neutrophil to Lymphocyte ratio (NLR), Fibrinogen to albumin ratio (FAR) and Urea to albumin ratio (UAR), which were created with the data obtained from laboratory parameters, were calculated mathematically.

CURB 65 was also calculated using the patients' pneumonia severity scores and recorded on the data collection form. The CURB-65 takes into account five risk factors: confusion or decreased consciousness, blood urea nitrogen $>7 \mathrm{mmol} / \mathrm{L}$, respiratory frequency $\geqslant 30 / \mathrm{min}$, systolic blood pressure $<90 \mathrm{mmHg}$ or diastolic blood pressure $\leqslant 60$ $\mathrm{mmHg}$, and age $\geqslant 65$ years.

\section{Statistical analysis}

Data were expressed as mean $\pm \mathrm{SD}$ for continuous variables and as percentages for categorical variables. The normal distribution of the variables was measured with the Kolmogorov-Smirnov test. The Student-t test was used to compare continuous variables with normal distribution, and the MannWhitney U-test was used to compare samples without normal distribution. Chi-square $\left(\chi^{2}\right)$ test was used to compare categorical variables. Fisher's exact test was used when the chi-square $\left(\chi^{2}\right)$ test conditions were not met. Kendall's tau_b and Spearmann correlation analysis were used for correlation analysis. The power of CURB-65 and laboratory parameters (CAR, NLR, FAR, UAR) to predict mortality was measured through ROC analysis. Sensitivity and specificity were calculated by finding a cut-off point that would have a high diagnostic accuracy for the parameters. Binary logistic regression analysis was applied using gender, age, comorbidities, CURB-65 and all laboratory parameters to identify predictors of mortality. As a result of the analysis, the parameters with Odds ratio above 1 are given in the table. SPSS 22.0 (SPSS 22.0 for Windows, Chicago, IL, USA) and MedCalc programs were used in the analysis. A p value of $<0.05$ was considered statistically significant for all analyses.

\section{RESULTS}

A total of 27364 patients were admitted to the emergency department during the study period. Throughout the study, 2518 patients were hospitalized for various reasons. $43.3 \%$ (n: 1090) of the hospitalized patients were hospitalized with a preliminary diagnosis of COVID-19 pneumonia. The study included 613 patients in whose Thoraks CT typical pneumonia findings (Table 1) was detected in the Tertiary hospital emergency department pandemic area and therefore hospitalized with the diagnosis of COVID-19 pneumonia. Of the 477 patients who were not included in the study, $211 \mathrm{did}$ not have undergo Thorax CT procedure, 15 patients did not have typical pneumonia, 196 patients' laboratory data could not be accessed and 16 were pregnant.

Hospitalized patients were divided into groups according to positive and negative RT-PCR results. Group 1 consisted of Suspected COVID-19 patients with typical pneumonia features on Thorax CT and negative RT-PCR test and Group 2 consisted of confirmed COVID-19 patients with typical pneumonia features on Thorax CT with positive RTPCR test. Group 1 and Group 2 constituted 66.4\% (n: 407) and 33.6\% (n: 206) of the total patients respectively (Table 1).

$41.6 \%$ (n: 255 ) of the total patients were female and $58.4 \%$ (n: 358 ) were male. While 68\% (n: 417 ) of the patients had at least one accompanying comorbidity, $39.3 \%$ (n: 241) had hypertension (HT) at most, $27.4 \%$ (n: 168) had coronary artery disease (CAD), 21.5\% (n: 132) had diabetes mellitus (DM). The presence of accompanying comorbidity was found to be statistically significant in terms of mortality $(\mathrm{p}<0.001)$ (Table 1). 
Table 1. Demographics and clinical presentation in COVID-19 pneumonia patients

\begin{tabular}{|c|c|c|c|c|c|c|c|}
\hline & $\begin{array}{l}\text { Total } \\
\text { (n: 613) }\end{array}$ & $\begin{array}{l}\text { Grup 1 } \\
(\mathrm{n}: 407 \% 66.4)\end{array}$ & $\begin{array}{l}\text { Grup2 } \\
(\mathrm{n}: 206 \% 33.6)\end{array}$ & $\mathrm{p}$ & $\begin{array}{l}\text { Survivor } \\
560(\% 91.4)\end{array}$ & $\begin{array}{l}\text { Non } \\
\text { Survivor } \\
53(\% 8.6)\end{array}$ & $\mathrm{p}$ \\
\hline \multicolumn{7}{|l|}{ Sex } & \multirow{3}{*}{0.387} \\
\hline Female & $255(41.6 \%)$ & $170(41.8 \%)$ & $85(41.3 \%)$ & & $230(41.1 \%)$ & $25(47.2 \%)$ & \\
\hline Male & $358(58.4 \%)$ & $237(58.2 \%)$ & $121(58.7 \%)$ & 0.931 & $330(58.9 \%)$ & $28(52.8 \%)$ & \\
\hline Age (year) & $59.04 \pm 19.5$ & $62 \pm 18.3$ & $53.3 \pm 20.4$ & $<0.001$ & $57.8 \pm 19.4$ & $71.8 \pm 16.4$ & $<0.001$ \\
\hline Fever $\left({ }^{\circ} \mathrm{C}\right)$ & $37.1 \pm 0.8$ & $37.03 \pm 0.8$ & $37.01 \pm 0.7$ & 0.164 & $37.1 \pm 0.7$ & $37.2 \pm 0.9$ & 0.198 \\
\hline Pulse (beats/min) & $95.3 \pm 22.3$ & $93.9 \pm 21.1$ & $98.1 \pm 24.4$ & 0.035 & $94.01 \pm 21.8$ & $108.9 \pm 23.9$ & $<0.001$ \\
\hline $\mathrm{MAP}(\mathrm{mmHg})$ & $86 \pm 19.3$ & $85.9 \pm 18.5$ & $86.1 \pm 20.8$ & 0.884 & $87.6 \pm 18.7$ & $68.3 \pm 16.8$ & $<0.001$ \\
\hline $\begin{array}{l}\text { Respiratory Rate } \\
\text { (beats/min) }\end{array}$ & $25.9 \pm 6.6$ & $25.7 \pm 6.5$ & $26.4 \pm 6.9$ & 0.201 & $25.3 \pm 6.5$ & $32.4 \pm 4.3$ & $<0.001$ \\
\hline Saturation (\%) & $93.3 \pm 5.9$ & $93.4 \pm 5.8$ & $93.1 \pm 6.2$ & 0.618 & $94.1 \pm 5.3$ & $84.6 \pm 5.4$ & $<0.001$ \\
\hline $\begin{array}{l}\text { Accompanying } \\
\text { Comorbidity }\end{array}$ & $417(68 \%)$ & $311(76.4 \%)$ & $106(51.5 \%)$ & $<0.001$ & $371(66.3 \%)$ & $46(86.8 \%)$ & $<0.001$ \\
\hline HT & $241(39.3 \%)$ & $162(40.0 \%)$ & $79(38.3 \%)$ & 0,793 & $227(40.5 \%)$ & $14(26.4 \%)$ & 0.055 \\
\hline $\mathrm{DM}$ & $132(21.5 \%)$ & $108(26.5 \%)$ & $24(11.7 \%)$ & $<0.001$ & $119(21.3 \%)$ & $13(24.5 \%)$ & 0.600 \\
\hline CAD & $168(27.4 \%)$ & $126(31.0 \%)$ & $42(20.4 \%)$ & 0,005 & $150(26.8 \%)$ & $18(34 \%)$ & 0,263 \\
\hline COPD & $89(14.5 \%)$ & $66(16.2 \%)$ & $23(11.2 \%)$ & 0.114 & $82(14.6 \%)$ & $7(13.2 \%)$ & 1.000 \\
\hline CVD & $55(9 \%)$ & $38(9.3 \%)$ & $17(8.3 \%)$ & 0,765 & $49(8.8 \%)$ & $6(11.3 \%)$ & 0,459 \\
\hline CKD & $55(9 \%)$ & $34(8.4 \%)$ & $21(10.2 \%)$ & 0,457 & $49(8.8 \%)$ & $6(11.3 \%)$ & 0,459 \\
\hline Cancer & $50(8.2 \%)$ & $40(9.8 \%)$ & $10(4.9 \%)$ & 0,041 & $39(7 \%)$ & $11(20.8 \%)$ & 0,002 \\
\hline Suspicious contact & $156(25.4 \%)$ & $57(14 \%)$ & $99(48.1 \%)$ & $<0.001$ & $153(27.3 \%)$ & $3(5.7 \%)$ & $<0.001$ \\
\hline Fever & $192(31.3 \%)$ & $123(30.2 \%)$ & $69(33.5 \%)$ & 0.409 & $176(31.4 \%)$ & $16(30.2 \%)$ & 1.000 \\
\hline Dry cough & $326(53.2 \%)$ & $214(52.6 \%)$ & $112(54.4 \%)$ & 0.732 & $308(55 \%)$ & $18(34 \%)$ & 0.004 \\
\hline Dyspnoea & $344(56.1 \%)$ & $236(58 \%)$ & $108(52.4 \%)$ & 0.197 & $295(52.7 \%)$ & $49(92.5 \%)$ & $<0.001$ \\
\hline Chest pain & $61(10 \%)$ & $45(11.1 \%)$ & $16(7.8 \%)$ & 0.253 & $55(9.8 \%)$ & $6(11.3 \%)$ & 0.637 \\
\hline Abdominal pain & $70(11.4 \%)$ & $45(11.1 \%)$ & $25(12.1 \%)$ & 0.689 & $66(11.8 \%)$ & $4(7.5 \%)$ & 0.498 \\
\hline Nausea - vomiting & $150(25.5 \%)$ & $98(24.1 \%)$ & $52(25.2 \%)$ & 0.766 & $138(24.6 \%)$ & $12(22.6 \%)$ & 0.868 \\
\hline $\begin{array}{l}\text { Symptoms onset to the } \\
\text { first visit,(day) }\end{array}$ & $3.8 \pm 2.0$ & $3.6 \pm 1.9$ & $4.2 \pm 2.1$ & $<0.001$ & $3.7 \pm 1.9$ & $4.3 \pm 2.1$ & 0.032 \\
\hline \multicolumn{4}{|c|}{ Emergency Service Outcome } & \multirow{4}{*}{0.501} & & \multirow{4}{*}{$<0.001$} \\
\hline & \multirow{2}{*}{$147(71.4 \%)$} & & & & \\
\hline Service & $448(73.1 \%)$ & $301(74 \%)$ & & & $442(78.9 \%)$ & $6(11.3 \%)$ & \\
\hline Intensive Care Unit & $165(26.9 \%)$ & $106(26 \%)$ & $59(28.6 \%)$ & & $118(21.1 \%)$ & $17(88.7 \%)$ & \\
\hline Mortality & $53(8.6 \%)$ & $40(9.8 \%)$ & $13(6.3 \%)$ & 0.171 & & & \\
\hline $\begin{array}{l}\text { Vasopressor } \\
\text { Requirement }\end{array}$ & $161(26.4 \%)$ & $84(20.7 \%)$ & $77(37.4 \%)$ & $<0.001$ & $121(21.6 \%)$ & $40(75.5 \%)$ & $<0.001$ \\
\hline MV Requirement & $148(24.2 \%)$ & $75(18.5 \%)$ & $73(35.4 \%)$ & $<0.001$ & $102(18.2 \%)$ & $46(86.8 \%)$ & $<0.001$ \\
\hline RRT & $69(11.3 \%)$ & $43(10.6 \%)$ & $26(12.6 \%)$ & 0.499 & $60(10.7 \%)$ & $9(17 \%)$ & 0.173 \\
\hline NIMV & $154(25.1 \%)$ & $101(24.8 \%)$ & $53(25.7 \%)$ & 0.844 & $132(23.6 \%)$ & $22(41.5 \%)$ & 0.007 \\
\hline $\begin{array}{l}\text { Lenght of Hospital } \\
\text { Stay }\end{array}$ & $9.5 \pm 9.6$ & $9.1 \pm 9.3$ & $10.1 \pm 10.1$ & 0.244 & $9.5 \pm 9.3$ & $9.1 \pm 12.1$ & 0.741 \\
\hline GGO & $351(57.3 \%)$ & $227(55.8 \%)$ & $124(60.2 \%)$ & 0.300 & $329(55.8 \%)$ & $22(41.5 \%)$ & 0.020 \\
\hline Consolidation & $133(21.8 \%)$ & $104(25.7 \%)$ & $29(14.1 \%)$ & 0.001 & $119(21.3 \%)$ & $14(26.4 \%)$ & 0.385 \\
\hline GGO + Consolidation & $227(37.2 \%)$ & $137(33.8 \%)$ & $90(43.7 \%)$ & 0.021 & $206(36.8 \%)$ & $21(39.6 \%)$ & 0.766 \\
\hline Wall thickening & $17(2.8 \%)$ & $11(2.7 \%)$ & $6(2.9 \%)$ & 1.000 & $17(3 \%)$ & $0(0 \%)$ & 0.385 \\
\hline Traction bronchiectasis & $12(2 \%)$ & $6(1.5 \%)$ & $6(2.9 \%)$ & 0.233 & $12(2.1 \%)$ & $0(0 \%)$ & 0.613 \\
\hline
\end{tabular}

Group 1: Suspected COVID 19 patients with typical pneumonia features on Thorax CT and negative RT-PCR test

Group 2: Confirmed COVID 19 patients with typical pneumonia on Thorax CT with positive RT-PCR test.

MAP: Mean arterial pressure HT: Hypertension, DM: Diabetes Mellitus, CAD: Coronary Artery Disease, COPD: Chronic Obstructive Pulmonary Disease, CVD: Cerebrovascular Disease CKD; Chronic Kidney Disease, RT-PCR; Real-time polymerase chain reaction, MV: Mechanical Ventilator, RRT: Renal Replacement Therapy, NIMV; Non-Invazive Mechanical Ventilator, GGO; Ground glass opacity

When the admission symptoms of the patients were examined, there was no statistically significant difference between the groups. Nevertheless, the presence of dry cough $(\mathrm{p}=0.004)$ and dyspnea $(\mathrm{p}<0.001)$ were found to be statistically significant in terms of mortality (Table 1).
Demographic data and vital parameters of COVID19 pneumonia patients are presented in Table 1. While $73.1 \%$ (n: 488 ) of the patients were admitted to the ward, $26.9 \%$ (n: 165) were admitted to the intensive care unit. The mean number of hospitalization days of the patients was determined to 
be $10.7 \pm 12.1$ days. $8.6 \%$ (n: 53 ) of our total patients died during their follow-up and treatment periods. When the groups were compared in terms of mortality, no statistically significant difference was found $(p=0.171)$. Demographic data and vital parameters of pneumonia patients are presented in Table 1. The mean CURB 65 score was $1.8 \pm 1.7$ in all of the patients. There was no statistically significant difference between the groups in terms of CURB 65 score $(p=0.360)$. When the relationship between CURB 65 and mortality was examined, the CURB-65 score was $1.6 \pm 1.6$ on average in survivor patients, while it was $4 \pm 1$ on average in non-survivor patients $(\mathrm{p}<0.001)$ (Table 2).

Table 2. Score and laboratory parameters in COVID 19 pneumonia patients

\begin{tabular}{|c|c|c|c|c|c|c|c|}
\hline & $\begin{array}{c}\text { Total } \\
(\mathrm{n}: 613)\end{array}$ & $\begin{array}{c}\text { Grup } 1 \\
(\mathrm{n}: 407 \\
\% 66.4)\end{array}$ & $\begin{array}{l}\text { Grup2 } \\
(\mathrm{n}: 206 \\
\% 33.6)\end{array}$ & $\mathrm{p}$ & $\begin{array}{c}\text { Survivor } \\
560(\% 91.4)\end{array}$ & $\begin{array}{c}\text { Non } \\
\text { Survivor } \\
53(\% 8.6)\end{array}$ & $\mathrm{p}$ \\
\hline CURB 65 & $1.8 \pm 1.7$ & $1.8 \pm 1.7$ & $1.7 \pm 1.9$ & 0.378 & $1.6 \pm 1.6$ & $4 \pm 1$ & $<0.001$ \\
\hline $\mathrm{LDH}(5-247 \mathrm{U} / \mathrm{L})$ & $359.7 \pm 404.3$ & $365.8 \pm 469$ & $347.9 \pm 228.4$ & 0.605 & $340.9 \pm 361.1$ & $558.5 \pm 691.6$ & 0.028 \\
\hline $\begin{array}{l}\text { Creatinine }(0.51-0.95 \\
\mathrm{mg} / \mathrm{dl})\end{array}$ & $1.6 \pm 2.0$ & $1.6 \pm 2.0$ & $1.6 \pm 2,1$ & 0.982 & $1.6 \pm 2.1$ & $2.1 \pm 1.8$ & 0.082 \\
\hline Ferritin $(11-307 \mu \mathrm{g} / \mathrm{L})$ & $416 \pm 715.1$ & $402.4 \pm 699.3$ & $442.9 \pm 746.4$ & 0508 & $308.8 \pm 475.7$ & $\begin{array}{c}1548.9 \pm 1467 \\
6\end{array}$ & $<0.001$ \\
\hline $\begin{array}{l}\text { Leukocyte (3.8-11.8 } \\
\left.10^{3} / \mu \mathrm{l}\right)\end{array}$ & $7.9 \pm 3.1$ & $8.02 \pm 3.2$ & $7.61 \pm 2.9$ & 0.136 & $7.8 \pm 3.1$ & $8.8 \pm 3.3$ & 0.025 \\
\hline $\begin{array}{l}\text { Neutrophils (1.9-8.2 } \\
\left.10^{3} / \mu \mathrm{l}\right)\end{array}$ & $6.8 \pm 2.4$ & $6.9 \pm 2.5$ & $6.6 \pm 2.2$ & 0.159 & $6.7 \pm 2.4$ & $8.1 \pm 2.6$ & $<0.001$ \\
\hline $\begin{array}{l}\text { Lymphocytes }(1.1-3.1 \\
\left.10^{3} / \mu \mathrm{l}\right)\end{array}$ & $1.2 \pm 0.7$ & $1.24 \pm 0.7$ & $1.2 \pm 0.5$ & 0.058 & $1.3 \pm 0.7$ & $0.8 \pm 0.4$ & $<0.001$ \\
\hline $\begin{array}{l}\text { Fibrinogen (180-350 } \\
\mathrm{mg} / \mathrm{dl})\end{array}$ & $359.1 \pm 234.7$ & $358.3 \pm 227.1$ & $360.8 \pm 249.4$ & 0.903 & $351.3 \pm 231.6$ & $441.8 \pm 252.5$ & 0.007 \\
\hline D-Dimer $(0-630 \mu \mathrm{g} / \mathrm{L})$ & $\begin{array}{c}2575.9 \pm 4644 . \\
2\end{array}$ & $\begin{array}{c}2759.4 \pm 4948 . \\
7\end{array}$ & $\begin{array}{c}2213.4 \pm 3961 \\
.3\end{array}$ & 0.169 & $\begin{array}{c}2259.1 \pm 427 \\
7.7\end{array}$ & $\begin{array}{c}5922.8 \pm 6681 \\
5\end{array}$ & $<0.001$ \\
\hline Hs-Tn I (0-16 ng/L) & $206.3 \pm 1283.5$ & $249.6 \pm 1472$ & $120.6 \pm 784.9$ & 0.158 & $\frac{178.6 \pm 1201}{3}$ & $498.4 \pm 1944.6$ & 0.245 \\
\hline $\mathrm{CRP}(0-5 \mathrm{mg} / \mathrm{l})$ & $70.9 \pm 76.8$ & $72.02 \pm 82$ & $68.7 \pm 65.7$ & 0.612 & $63.9 \pm 70.9$ & $145.2 \pm 96.6$ & $<0.001$ \\
\hline Albumin $(35-55 \mathrm{~g} / \mathrm{l})$ & $33.6 \pm 5.4$ & $33.3 \pm 5.6$ & $34.1 \pm 5,1$ & 0.091 & $34.04 \pm 5.2$ & $28.7 \pm 5,7$ & $<0.001$ \\
\hline PCT $(0-0.065 \mu \mathrm{g} / \mathrm{L})$ & $0.36 \pm 1$ & $0.34 \pm 0.54$ & $0.39 \pm 1.5$ & 0.617 & $0.32 \pm 1$ & $0.84 \pm 1.1$ & 0.001 \\
\hline CAR & $2.4 \pm 2.9$ & $2.4 \pm 3.1$ & $2.3 \pm 2.6$ & 0.582 & $2.1 \pm 2.6$ & $5.6 \pm 4.2$ & $<0.001$ \\
\hline NLR & $8.2 \pm 8.9$ & $8.7 \pm 10.1$ & $7.3 \pm 5.7$ & 0.037 & $7.8 \pm 8.8$ & $12.8 \pm 8.7$ & $<0.001$ \\
\hline FAR & $11.1 \pm 7.8$ & $11.2 \pm 7.7$ & $11 \pm 8.1$ & 0.781 & $10.7 \pm 7.5$ & $15.8 \pm 8.9$ & $<0.001$ \\
\hline UAR & $1.9 \pm 1.8$ & $2 \pm 1.9$ & $1.7 \pm 1.7$ & 0.153 & $1.7 \pm 1.6$ & $3.6 \pm 3$ & $<0.001$ \\
\hline
\end{tabular}

Group 1: Suspected COVID 19 patients with typical pneumonia features on Thorax CT and negative RT-PCR test

Group 2: Confirmed COVID 19 patients with typical pneumonia features on Thorax CT with positive RT-PCR test.

CURB-65: Confusion, Urea, Respiratory Rate, Blood Pressure and Age $\geq 65$, LDH; Lactate dehydrogenase, hs-Tn I; High Sensitivity Troponin I, CRP; C-reaktive protein, PCT; Procalcitonin, CAR: CRP/Albumin Ratio, NLR; Neutrophils/Lymphocytes Ratio, FAR: FibrinoJen/Albumin Ratio; UAR: Ure/Albumin Ratio

Table 3. ROC analysis of the mortality prediction of CURB 65 and laboratory parameters in COVID-19 pneumonia patients

\begin{tabular}{|l|c|c|c|c|c|}
\hline & AUC (\%95 CI) & Cut off & $\mathbf{p}$ & Sensitivity (\%) & Specifity (\%) \\
\hline CURB65 & $0.869(0.832-0.905)$ & 2.5 & $<0.001$ & 96.2 & 70.2 \\
\hline CAR & $0.790(0.728-0.852)$ & 2.1561 & $<0.001$ & 73.6 & 68.4 \\
\hline UAR & $0.750(0.683-0.816)$ & 1.5622 & $<0.001$ & 73.6 & 67 \\
\hline NLR & $0.743(0.686-0.801)$ & 7.7321 & $<0.001$ & 67,9 & 67.5 \\
\hline FAR & $0.668(0.594-0.742)$ & 11.1078 & $<0.001$ & 62.3 & 57.5 \\
\hline
\end{tabular}

AUC: Areas under the curve, SE: Standart Error, CI: Confidence Interval, CURB-65: Confusion, Urea, Respiratory Rate, Blood Pressure and Age $\geq 65$, CAR: CRP/Albumin Ratio, NLR; Neutrophils/Lymphocytes Ratio, FAR: Fibrinojen/Albumin Ratio; UAR: Ure/Albumin Ratio

When the laboratory parameters of the patients were examined, it was determined that LDH, Ferritin, Ddimer, Troponin, Fibrinogen, CRP and PCT values were high, while lymphocyte and albumin values were low. There was no statistically significant difference between the groups in terms of laboratory 
parameters. All laboratory parameters except for troponin $(\mathrm{p}=0.245)$ and creatinine $(\mathrm{p}=0.082)$ were significantly different in survivor and non-survivor groups. While CRP/Albumin ratio (CAR) was $2.1 \pm 2.6$ on average in survivor patients, it was $5.6 \pm 4.2$ on average in non-survivor patients ( $p$ $<0.001)$. Scores and Laboratory Parameters in COVID-19 pneumonia patients are presented in Table 2.

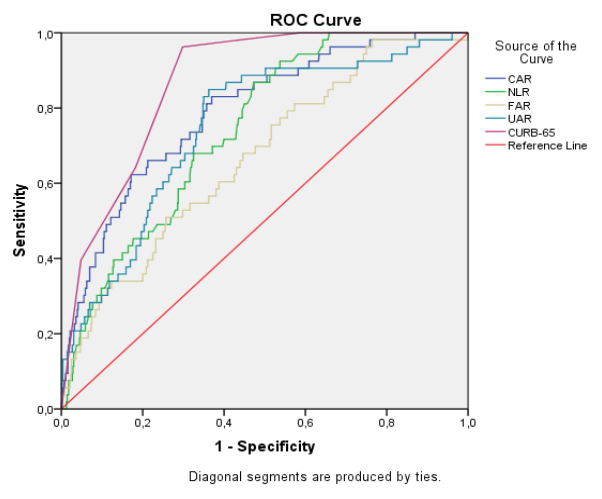

Figure 1. The graphic of ROC analysis performed to determine the mortality predictive characteristics of CURB 65 and laboratory parameters in COVID-19 pneumonia patients

CURB-65: Confusion, Urea, Respiratory Rate, Blood Pressure and Age $\geq 65$, CAR: CRP/Albumin Ratio, NLR; Neutrophils/Lymphocytes Ratio, FAR: Fibrinojen/Albumin Ratio; UAR: Ure/Albumin Ratio

Table 4. Binary logistic regression analysis for mortality

\begin{tabular}{|l|c|c|c|}
\hline & & & \\
Variables & Odds Ratio & $\mathbf{9 5 \%}$ Confidence Interval & $\mathbf{p}$ \\
\hline CURB-65 & 3.416 & $2.337-4.995$ & 0.000 \\
\hline CAR & 1.217 & $1.078-1.373$ & 0.001 \\
\hline NLR & 1.018 & $0.990-1.047$ & 0.207 \\
\hline FAR & 1.005 & $0.956-1.057$ & 0.843 \\
\hline
\end{tabular}

Binary Logistic Regression by Mortality; Variable(s): gender, age, comorbidities, CURB-65, All Laboratory Parameters

CURB-65: Confusion, Urea, Respiratory Rate, Blood Pressure and Age $\geq 65$, CAR: CRP/Albumin Ratio, NLR; Neutrophils/Lymphocytes Ratio, FAR: Fibrinojen/Albumin Ratio;

\section{DISCUSSION}

In this study, we compared the predictive power of mortality the CRP to albumin ratio (CAR) with the CURB 65 score in patients hospitalized for COVID19 pneumonia. In the analytical evaluation for mortality, the AUC of CURB 65 was 0.869 , the AUC of CAR was 0.790 . According to our study data, a cutoff value of CAR above 2.2 may be an indicator
The ability of CAR, NLR, FAR, UAR and CURB 65 to predict in-hospital mortality was assessed using receiver operating characteristic (ROC) curves. The graphic of ROC analysis performed to determine the mortality predictive characteristics of CURB-65, CAR, NLR, FAR and UAR in the whole patients has been presented in Figure 1. When the ROC analysis performed to determine the mortality predictive characteristics of the scores was examined, it was determined that the AUC value of the CURB-65 (AUC: $0.86995 \%$ CI $0.832-0.905, \mathrm{p}<0.001$ ) was the highest. When the cut-off value of CURB 65 was taken as 2.5 to predict mortality, the sensitivity was calculated as $96.2 \%$ and the specificity was calculated as $70.2 \%$. CAR (AUC: $0.790,95 \%$ CI $0.728-0.852$, p $<0.001)$ was found to be the highest of the laboratory parameters (Table 3).

Binary logistic regression analysis was applied using gender, age, comorbidities, CURB-65, all laboratory parameters determined in our study to determine the effective predictors of mortality. As a result of the analysis, the parameters with Odds ratio above 1 are given in the table. The Analysis indicated a 3.4-fold increased risk for mortality for each unit increase in CURB-65 value in COVID-19 pneumonia patients $(\mathrm{OR}=3.416,95 \% \mathrm{CI}: 2.337-4.995, \mathrm{p}<0.001)$ and 1.2-fold increased risk for mortality for each unit increase in CAR value $(\mathrm{OR}=1.217, \% 95 \mathrm{CI}$ : 1.078 1.373, $\mathrm{p}<0.001$ ) (Table 4). 
patients with CURB-65 scores of 0 and 1 be treated as an outpatient, those with a CURB-65 score of 2 should be hospitalized, and patients with a CURB-65 score of 3 or above should be evaluated for ICU admission ${ }^{19}$. In our study, $51.4 \%$ of the patients had a CURB 65 score of 0 and 1,13.1\% had a CURB 65 score of 2 , and $35.6 \%$ had a CURB 65 score of 3 and above. Among the patients with a CURB 65 score of 0 or 1 , we did not have any mortal patients. Since our study covered the first period of the pandemic period, patients with pneumonia were monitored and treated in hospital in isolation due to the COVID-19 epidemic, even if their CURB 65 score was 0 or 1 . When the ROC analysis conducted to determine the predictive features of mortality was examined, it was determined that the AUC value of CURB-65 (AUC: $0.86995 \%$ CI $0.832-0.905, \mathrm{p}<0.001$ ) was the highest. According to the study data, it was seen that the CURB-65 score calculated in the emergency department strongly predicted the mortality of pneumonia patients in the COVID-19 pandemic.

As reported in recent publications, ground-glass opacities on Thorax CT including multifocal irregular consolidation and/or peripherally distributed interstitial changes appear as typical radiographic features in almost all COVID-19 patients ${ }^{20,21}$. These changes seen on Thorax CT were also observed in patients who had negative RT-PCR results but their clinical symptoms matched with COVID-19 Pneumonia. Small-scale studies have shown that the current RT-PCR test has limited sensitivity and that Thorax CT can reveal pulmonary changes consistent with COVID-19 even in patients with initial negative RT-PCR results ${ }^{22}$, 23. Patients with thorax CT compatible with typical COVID-19 pneumonia (CORADS 4 and 5) were included in the study. There was no statistically significant difference between the patients with negative RT-PCR test and those with positive RT-PCR test in terms of laboratory parameters. Laboratory parameters were consistent with COVID-19 pneumonia in both groups. Our data suggest that if there are clinical symptoms and thorax CT imaging features during the pandemic period, these patients should be isolated and treated in the early period, even if the RT-PCR test is negative.

The clinical features of COVID-19, which emerges with pneumonia symptoms, are still under investigation. COVID-19 is a systemic disease and the severity of the disease may be associated with the emergence of "cytokine storm syndrome" triggered by increased inflammatory markers [C-reactive protein (CRP), Procalcitonin (PCT), Neutrophil] ${ }^{24}$. It has been shown that increased serum ferritin, Ddimer, troponin I and lactate dehydrogenase (LDH) and lymphopenia are associated with poor prognosis and increased mortality ${ }^{25-28}$. In a meta-analysis, it was stated that CRP concentrations were high in patients who died of COVID-19 and that CRP could be used to assess severity of the disease ${ }^{29}$. It has been reported that COVID 19 patients with low Albumin levels have a higher risk of mortality ${ }^{30,31}$. The patients in our study had low lymphocyte and albumin levels and high D-dimer, Fibrinogen, Ferritin, CRP and LDH levels, which were statistically significant in terms of mortality.

Recently, many simple inflammatory markers have been used as systemic inflammation markers to predict mortality in pneumonia patients ${ }^{32-34}$. In this study, we calculated the NLR, CAR, UAR and FAR values mathematically by using the emergency department laboratory parameters of the patients at the first admission and compared them with the outcomes of pneumonia patients during the pandemic. It is thought that the inflammatory cytokine storm may be associated with the progression of COVID-1935-37. CRP is an acute phase protein synthesized from hepatocytes in inflammatory conditions ${ }^{38,39}$. Albumin is used as a negative acute phase reactant as a result of increased catabolism, inflammation, and decreased hepatic synthesis of the cytokine TNF- $\alpha^{40}$. Therefore, CRP to albumin ratio (CAR) can be considered as an important and sensitive predictor of systemic inflammatory response. High CAR has started to be used as a mortality indicator in new studies conducted in ICU inpatients ${ }^{13}, 14,41,42$. In study on COVID patients, Wang et al. found CAR to be associated with the severity of the COVID-19 disease ${ }^{43}$.

In studies conducted as regards pneumonia patients before the pandemic, it was found that high Neutrophil to lymphocyte ratio (NLR) predicted mortality ${ }^{44,45}$ and admission to intensive care unit ${ }^{46}$. It has been stated that high NLR may be an independent prognostic biomarker that determines the severity of pneumonia in COVID-19 patients ${ }^{47}$. In another study, it was shown that severe COVID19 cases tended to have high $\mathrm{NLR}^{48}$. Fibrinogen to albumin ratio (FAR) ${ }^{49-51}$ and Urea to albumin ratio (UAR) ${ }^{52-54}$ were studied in community-acquired pneumonia patients in some previous studies, and high FAR and UAR values were found to be 
associated with mortality. In a study conducted in COVID 19 patients, increased UAR ratio ${ }^{55}$ and increased FAR $^{56}$ were associated with increased mortality risk. In our study, inflammatory biomarkers (CAR, NLR, FAR, and UAR) were found to have a statistically significant relationship with mortality while the AUC value of CAR was the highest in the ROC analysis for mortality. When compared with NLR, FAR and UAR according to the study data, CAR (OR=1.217, 95\% CI: 1.078-1.373, p <0.001) was observed as an independent risk factor for mortality in pneumonia patients. The fact that our study was single-centered and retrospective may be a limitation, as drawing out generalizations for all patients through the findings of this study conducted in a single hospital may cause misconceptions.

In conclusion if there are clinical symptoms, epidemiological features and Thorax CT imaging features of viral pneumonia compatible with COVID-19 infection, these patients should be isolated and treated in the early period, even if their RT-PCR tests are negative. Since the emergency departments have been rather busy recently, high CRP to albumin ratio (CAR) can identify COVID-19 pneumonia patients with poor prognosis during the pandemic, ensuring rapid isolation and effective treatment.

Yazar Katkıları: Calısma konsepti/Tasarımı: SA, MG, SS, NU, AK, CI, CI, HES; Veri toplama: SA, BTF, GKS, Ci, CI, AK; Veri analizi ve yorumlama: SA, SS, MG, AC, HES, NU; Yazı taslağı: SA, MG, CI, AK, NU, Çİ, BTF, GKS, HES, SS; İçeriğin eleştirel incelenmesi: SA, MG SS, HES; Son onay ve sorumluluk: SA, MG, CI, AK, NU, ÇI, BTF, GKS, HES, SS; Teknik ve malzeme desteği: SA, SS, BTF, GKS, Ç, AK Süpervizyon: SA, SS, HES, CI, NU; Fon sağlama (mevcut ise): yok.

Etik Onay: Bu çalışma için Adana Şehir Eğitim ve Araştırma Hastanesi Klinik Araştırmalar Etik Kurulundan 06.05.2020 tarih ve 841/56 sayil kararı ile etik onay alınmıştır.

Hakem Değerlendirmesi: Dış bağımsız.

Çıkar Catışması: Yazarlar çıkar çatısmasısı beyan etmemișlerdir.

Finansal Destek: Bu araştırma, kamu, ticari veya kar amacı gütmeyen sektörlerdeki finansman kuruluşlarından belirli bir hibe almadı.

Yazarın Notu: Çalışmanın Plan ve Veri Toplama esnasında emeği olan ve Covid nedeniyle hayatına kaybeden değerli meslektaşımız Dr. Mehmet Ertane'ye saygilarımızla.

Author Contributions: Concept/Design : SA, MG, SS, NU, AK, CI, Çİ, HES; Data acquisition: SA, BTF, GKS, ÇI, CI, AK; Data analysis and interpretation: SA, SS, MG, AC, HES, NU; Drafting manuscript: SA, MG, CI, AK, NU, ÇI, BTF, GKS, HES, SS; Critical revision of manuscript: SA, MG, SS, HES; Final approval and accountability: SA MG, CI, AK, NU, Çİ, BTF, GKŞ, HES, SS; Technical or material support: SA, SS, BTF, GKS, Çİ, AK; Supervision: SA, SS, HES, CI, NU, Securing funding (if available): $\mathrm{n} / \mathrm{a}$.

Peer-review: Externally peer-reviewed.

Conflict of Interest: Authors declared no conflict of interest.

Financial Disclosure: This research did not receive any specific gran from funding agencies in the public, commercial, or not-for-profi sectors.

Acknowledgement: With our endless respects to our dear colleague, emergency medicine assistant doctor Mehmet Ertane, who contributed to the planning and data collection phase of the publication and died due to COVID.

\section{REFERENCES}

1. Yang T, Wan C, Wang H, Qin J, Chen L, Shen Y et al. The prognostic and risk-stratified value of neutrophillymphocyte count ratio in Chinese patients with community-acquired pneumonia. Eur J Inflamm. 2017:15:22-27.

2. Feng DY, Zou XL, Zhou YQ, Wu WB, Yang HL, Zhang TT. Combined neutrophil-to-lymphocyte ratio and CURB-65 score as an accurate predictor of mortality for community-acquired pneumonia in the elderly. Int J Gen Med. 2021;14:1133-9.

3. Shereen MA, Khan S, Kazmi A, Bashir N, Siddique R. COVID-19 infection: Origin, transmission, and characteristics of human coronaviruses. J Adv Res. 2020;24:91-8.

4. Charles PG, Davis JS, Grayson ML. Rocket science and the Infectious Diseases Society of America/American Thoracic Society (IDSA/ATS) guidelines for severe community-acquired pneumonia. Clin Infect Dis. 2009;48:1796-7.

5. Zhang ZX, Yong Y, Tan WC, Shen L, Ng HS, Fong KY. Prognostic factors for mortality due to pneumonia among adults from different age groups in Singapore and mortality predictions based on PSI and CURB-65. Singapore Med J. 2018;59:190-8.

6. Noguchi S, Yatera K, Kawanami T, Fujino Y, Moro H, Aoki N. Pneumonia severity assessment tools for predicting mortality in patients with healthcareassociated pneumonia: a systematic review and metaanalysis. Respiration. 2017;93:441-50.

7. Wang X, Jiao J, Wei R, Feng Y, Ma X, Li Y et al. A new method to predict hospital mortality in severe community acquired pneumonia. Eur J Intern Med. 2017;40:56-63.

8. Fujikura Y, Kawano S, Kouzaki Y, Shinoda M, Hara Y, Shinkai M. Mortality and severity evaluation by routine pneumonia prediction models among Japanese patients with 2009 pandemic influenza A (H1N1) pneumonia. Respir Investig. 2014;52:280-7.

9. Satici C, Demirkol MA, Sargin AE, Gursoy B, Alkan M, Kamat $S$ et al. Performance of pneumonia severity index and CURB-65 in predicting 30-day mortality in patients with COVID-19. Int J Infect Dis. 2020;98:849 .

10. Zhou F, Yu T, Du R, Fan G, Liu Y, Liu Z. Clinical course and risk factors for mortality of adult inpatients with COVID-19 in Wuhan, China: a retrospective cohort study. Lancet. 2020;395:1054-62.

11. Oh TK, Ji E, Na HS, Min B, Jeon YT, Do SH. Creactive protein to albumin ratio predicts 30-day and 1 -year mortality in postoperative patients after admission to the intensive care unit. J Clin Med. 2018;7:39.

12. Quispe EA, Li XM, Yi H. Comparison and relationship of thyroid hormones, IL-6, IL-10 and albumin as mortality predictors in case-mix critically ill patients. Cytokine. 2016;81:94-100. 
13. Kim MH, Ahn JY, Song JE, Choi H, Ann HW, Kim $\mathrm{JK}$ et al. The $\mathrm{C}$-reactive protein/albumin ratio as an independent predictor of mortality in patients with severe sepsis or septic shock treated with early goaldirected therapy. PLoS One. 2015;10:e0132109.

14. Sun R, Sun X, Yang H, Liu Q. Retrospective analysis of serum C-reactive protein/albumin ratio for the prognosis of the adult patients with sepsis. Zhonghua Wei Zhong Bing Ji Jiu Yi Xue. 2016;28:413-7.

15. Wu M, Guo J, Guo L, Zuo Q. The C-reactive protein/albumin ratio predicts overall survival of patients with advanced pancreatic cancer. Tumour Biol. 2016;37:12525-33.

16. COVID working group of the Dutch Radiological Society, 2020. COVID-19 CORADS Classification. Available https://radiologyassistant.nl/chest/COVID-19corads-classification. Accessed April 19, 2020.

17. Prokop M, van Everdingen W, van Rees Vellinga $T$, Quarles van Ufford H, Stöger L, Beenen L. CORADS-A categorical CT assessment scheme for patients with suspected COVID-19: definition and evaluation. Radiology. 2020;296:E97-104.

18. Marti C, Garin N, Grosgurin O, Poncet A, Combescure C, Carballo S et al. Prediction of severe community acquired pneumonia: a systematic review and meta-analysis. Crit Care. 2012;16:141.

19. Wunderink RG, Waterer G. Advances in the causes and management of community acquired pneumonia in adults. BMJ. 2017;10;358;j247.

20. Chung M, Bernheim A, Mei X, Zhang N, Huang M, Zeng X et al. CT imaging features of 2019 novel coronavirus (2019-nCoV). Radiology. 2020;295:202-7.

21. Ai T, Yang Z, Hou H, Zhan C, Chen C, Lv W et al. Correlation of Chest CT and RT-PCR testing in Coronavirus Disease 2019 (COVID-19) in China: A report of 1014 cases. Radiology. 2020;296:E32-40.

22. Huang P, Liu T, Huang L, Liu H, Lei M, Xu W et al. Use of chest CT in combination with negative RTPCR assay for the 2019 novel coronavirus but high clinical suspicion. Radiology 2020;295:22-3.

23. Xie X, Zhong Z, Zhao W, Zheng C, Wang F, Liu J. Chest CT for typical 2019-nCoV pneumonia: relationship to negative RT-PCR testing. Radiology. 2020;296:E41-5.

24. Skevaki C, Fragkou PC, Cheng C, Xie M, Renz H. Laboratory characteristics of patients infected with the novel SARS-CoV-2 virus. J Infect. 2020;81:20512.

25. Wu J, Liu J, Zhao X, Liu C, Wang W, Wang D et al. Clinical characteristics of imported cases of COVID19 in Jiangsu province: a multicenter descriptive study. Clin Infect Dis. 2020;71:706-12.

26. Yang X, Yu Y, Xu J, Shu H, Xia J, Liu H et al. Clinical course and outcomes of critically ill patients with SARS-CoV-2 pneumonia in Wuhan, China: a singlecentered, retrospective, observational study. Lancet Respir Med. 2020;8:475-81.
27. Ji D, Qin E, Xu J, Zhang D, Cheng G, Wang Y et al. Implication of non-alcoholic fatty liver diseases (NAFLD) in patients with COVID-19: a preliminary analysis. J Hepatol. 2020; doi:10.1016/j.jhep.2020.03.044.

28. Liu Y, Du X, Chen J, Jin Y, Peng L, Wang HHX et al. Neutrophil-to-lymphocyte ratio as an independent risk factor for mortality in hospitalized patients with COVID-19. J Infect. 2020;81:e6-12.

29. Sahu BR, Kampa RK, Padhi A, Panda AK. C-reactive protein: A promising biomarker for poor prognosis in COVID-19 infection. Clin Chim Acta. 2020;509:91-4.

30. Gong J, Ou J, Qiu X, Jie Y, Chen Y, Yuan L et al. A tool to early predict severe corona virus disease 2019 (COVID-19): A multicenter study using the risk nomogram in Wuhan and Guangdong, China. Clin Infect Dis. 2020;28;71:833-40.

31. Tian W, Jiang W, Yao J, Nicholson CJ, Li RH, Sigurslid $\mathrm{HH}$ et al. Predictors of mortality in hospitalized COVID-19 patients: A systematic review and meta-analysis. J Med Virol. 2020;92:1875-83.

32. Huang Y, Liu A, Liang L, Jiang J, Luo H, Deng W et al. Diagnostic value of blood parameters for community-acquired pneumonia. Int Immunopharmacol. 2018;64:10-5.

33. Kartal O, Kartal AT. Value of neutrophil to lymphocyte and platelet to lymphocyte ratios in pneumonia. Bratisl Lek Listy. 2017;118:513-6.

34. Zhang HF, Ge YL, Wang HY, Zhang Q, Li WQ, Chen $\mathrm{Y}$ et al. Neutrophil-to-lymphocyte ratio improves the accuracy and sensitivity of pneumonia severity index in predicting 30-day mortality of CAP patients. Clin Lab. 2019;65:10.

35. Ye Q, Wang B, Mao J. The pathogenesis and treatment of the 'cytokine storm' in COVID-19. J Infect. 2020;80:607-13.

36. Coperchini F, Chiovato L, Croce L, Magri F, Rotondi $\mathrm{M}$. The cytokine storm in COVID-19: an overview of the involvement of the chemokine/chemokinereceptor system. Cytokine Growth Factor Rev. 2020;53;25-32

37. Ragab D, Salah Eldin H, Taeimah M, Khattab R, Salem R. The COVID-19 cytokine storm; what we know so far. Front Immunol. 2020;11:1446.

38. Nozoe T, Korenaga D, Futatsugi M, Saeki H, Maehara Y, Sugimachi K. Immunohistochemical expression of C-reactive protein in squamous cell carcinoma of the esophagus - significance as a tumor marker. Cancer Lett. 2003;192:89-95.

39. Song Y, Liu Y, Zhou Z, Yang W, Zhou Y. The clinical study of serum hs-CRP, TNF- $\alpha$, PCT and IL- 6 in patients with acute exacerbation of chronic obstructive pulmonary disease. Int J Clin Exp Med. 2017;10:13550-6.

40. Yang WM, Zhang WH, Ying HQ, Xu YM, Zhang J, Min $\mathrm{QH}$ et al. Two new inflammatory markers associated with disease activity score- 28 in patients with rheumatoid arthritis: albumin to fibrinogen ratio 
and C-reactive protein to albümin ratio. Int Immunopharmacol. 2018; 62:293-8.

41. Ranzani OT, Zampieri FG, Forte DN, Azevedo LC, Park M. C-reactive protein/albumin ratio predicts 90day mortality of septic patients. PLoS One. 2013;8:e59321.

42. Park JE, Chung KS, Song JH, Kim SY, Kim EY, Jung JY et al. The C-reactive protein/albumin ratio as a predictor of mortality in critically ill patients. J. Clin. Med. 2018;7:333.

43. Wang X, Xu Y, Huang H, Jiang D, Zhou C, Liao H et al. Increased pretreatment C-reactive protein-toalbumin ratio predicts severe coronavirus disease 2019. Research Square. 2020; doi:10.21203/rs.3.rs$31723 / \mathrm{v} 2$.

44. de Jager CP, Wever PC, Gemen EF, Kusters R, van Gageldonk-Lafeber AB, van der Poll $\mathrm{T}$ et al. The neutrophil-lymphocyte count ratio in patients with community-acquired pneumonia. PLoS One. 2012;7:e46561.

45. Song Y, Sun W, Dai D, Liu Y, Li Z, Tian Z et al. Prediction value of procalcitonin combining CURB65 for 90-day mortality in community-acquired pneumonia. Expert Rev Respir Med. 2021;15:689-96.

46. Cataudella E, Giraffa CM, Di Marca S, Pulvirenti A, Alaimo S, Pisano M et al. Neutrophil-to-lymphocyte ratio: an emerging marker predicting prognosis in elderly adults with community-acquired pneumonia. J Am Geriatr Soc. 2017;65:1796-801.

47. Yang AP, Liu JP, Tao WQ, Li HM. The diagnostic and predictive role of NLR, d-NLR and PLR in COVID19 patients. Int Immunopharmacol. 2020; 84:106504.

48. Qin C, Zhou L, Hu Z, Zhang S, Yang S, Tao Y et al. Dysregulation of immune response in patients with COVID-19 in Wuhan, China. Clin Infect Dis. 2020;28;71:762-8

49. Luo B, Sun M, Huo X, Wang Y. Two new inflammatory markers related to the CURB-65 score for disease severity in patients with communityacquired pneumonia: The hypersensitive C-reactive protein to albumin ratio and fibrinogen to albumin ratio. Open Life Sci. 2021;16:84-91.

50. Li T, Yu H, Hou W, Li Z, Han C, Wang L. Evaluation of variation in coagulation among children with Mycoplasma pneumoniae pneumonia: a case-control study. J Int Med Res. 2017;45:2110-8.

51. Chen L, Lu XY, Zhu CQ. Prognostic value of albumin-red cell distribution width score in patients with severe community-acquired pneumonia. Ann Palliat Med. 2020;9:759-65.

52. Feng DY, Zhou YQ, Zou XL, Zhou M, Yang HL, Chen XX et al. Elevated blood urea nitrogen-to-serum albumin ratio as a factor that negatively affects the mortality of patients with hospital-acquired pneumonia. Can J Infect Dis Med Microbiol. 2019;2019:1547405.

53. Ugajin M, Yamaki K, Iwamura N, Yagi T, Asano T. Blood urea nitrogen to serum albumin ratio independently predicts mortality and severity of community acquired pneumonia. Int J Gen Med. 2012;5:583-9.

54. Akpınar EE, Hoşgün D, Doganay B, Gülhan M. The role of albumin level and blood urea nitrogen/ albumin ratio in prediction of prognosis of community acquired pneuomonia. J Pulm Respir Med. 2013;3:159.

55. Marwah M, Marwah S, Blann A, Morrissey H, Ball P, Wandroo FA. Analysis of laboratory blood parameter results for patients diagnosed with COVID-19, from all ethnic group populations: A single centre study. Int J Lab Hematol. 2021; doi:10.1111/ijlh.13538.

56. Küçükceran K, Ayranci MK, Girişgin AS, Koçak S. Predictive value of $\mathrm{D}$-dimer/albumin ratio and fibrinogen/albumin ratio for in-hospital mortality in patients with COVID-19. Int J Clin Pract. 2021;75:e14263. 